\title{
Historical and Comparative Analysis of Changes in the Albanian Penal Code. The Criminalization of Behaviours and Severity of Punishment
}

\author{
Aleks Nikolli \\ European University of Tirana \\ Email: alnikolli@live.com
}

\section{Doi:10.5901/mjss.2015.v6n1p300}

\section{Abstract}

Purpose:The new Albanian Penal Code has undergone 15 amendments since its adoption. This paper will discuss in chronological and comparative terms the developments of the new Albanian Penal Code of 1995, focusing on criminalization of conduct and on the toughening of punishments. The paper aims to assess the criteria used by the legislator regarding the need for changes in the Albanian Criminal Code and penal policy regarding the severity levels of the criminal sanctions.Materials and methods: In this study we refer to the text of the communist Penal Code of 1977, the new Criminal Code of 1995 and the texts of 15 laws that have changed the Penal Code over the last 19 years. For the analysis of theoretical aspects of this paper we have used a wide range of domestic and foreign literature on the research topic, as well as jurisprudence of the Constitutional Court of the Republic of Albania. Conclusions were drawn with the use of comparisons between the Albanian Penal Code and the Criminal Codes of France, Germany, Italy and Kosovo. Conclusions:The findings of this paper are that the frequent changes to the Albanian Criminal Code have been made hastily and do not show a deep and farsighted reflection of the legislator, in order to ensure that these changes will be enduring and stand the test of time. A large part of the changes are due to reflex reactions to populist solutions of the day and thus are dominated by a strong tendency to constantly be stiffening the sentences.

Keywords: Severe sentence, punishment, criminalization, penal policy, Albanian Penal Code;

\section{Introduction}

Criminal law is a branch of the legal system of a country by which it is determined what kind of human actions constitute a criminal offence and, if proven guilty, what sanctions should be dealt for them (Salihu, 2012, p. 25). Criminal law therefore can be considered as dealing with two issues; first, the definition of the conditions and criteria of criminal responsibility of a suspected offender (actus reus and mens rea) and second, the conditions and criteria determining the actual sanctions that will be stipulated for the author of that behaviour (Kambovski, 2007, p. 17). The issue of whether or not certain conduct should be criminalized has consistently fed the political, sociological, ethical and criminal justice scholarly debate. According to Jonathan Herring (2012, p.2), it is very difficult to give a definitive answer as to what is a crime, because the answer depends very much on the perspective of the author.

Undoubtedly whether or not given conduct will be considered as criminal can change over time, depending on political, social or economic changes, or which country you live in. For example, legal responses to homosexual activity have changed over recent decades in response to a variety of social, political, and legal influences. Also, during the communist regime in Albania, a criminal offence widely applied in judicial practice was Article 55 of the former Criminal Code concerning "Agitation and propaganda", while under the democratic system, freedom of thought and speech are two basic principles of the functioning of such a society. In addition, there is a significant difference between the criminal law of Western European countries and Arab countries (Dammer \& Fairchild, 2006, p. 66). Globalization has meant that not only are the most serious criminal offences such as murder, robbery, rape and kidnapping considered universal, but also the number of offences that are considered "typically exclusive of a particular country" are now smaller (Muncie, 2011, p. 88).

The issue of criminalization of certain behaviours is just one of the problems that concerns criminal law, and similarly, but in practical terms, an issue of greater sensitivity is that of determining the penal sanctions for conduct already established as a criminal offence. With the proliferation and diversification of criminal sanctions, the selection of one sanction, from the harshest to the mildest, has great significance as it can completely change the meaning of the criminal law.

On 27 January 1995 Albania brought in a new Penal Code and, on 21 March 1995, a new Criminal Procedure 
Code. Although their adoption was considered a major achievement in terms of aligning Albanian criminal legislation with Western European countries (Islami, Hoxha, \& Panda, 2003, p. 32), it soon became necessary to make changes and additions. Although at first this was induced by the many original shortcomings of the Code, it has become an ongoing tendency of Albanian governments to make additions and changes to both the General Part and particularly the Special Part of the Albanian Criminal Code, justifying the changes by the need to combat criminality. This paper will discuss in chronological and comparative terms the developments of the new Albanian Penal Code of 1995, focusing on criminalization of conduct and on the toughening of the punishments. The frequent changes, in terms of enacting new offences and imposing tougher criminal sanctions, will be analyzed critically, to identify their enduring quality and their effect on the principle of legal security and reducing criminality.

Materials and methods

In this study we refer to the text of the communist Penal Code of 1977, the new Criminal Code of 1995 and the texts of 15 laws that have changed the Penal Code over the last 19 years. The detailed historical presentation of the criminal legislation is done in order to draw grounded conclusions regarding the criminal policy pursued in Albania after 1995 towards the criminalization of behaviors and the severity of criminal sanctions. For the analysis of theoretical aspects of this paper we have used a wide range of domestic and foreign literature on the research topic, as well as jurisprudence of the Constitutional Court of the Republic of Albania. Following the historical analysis, conclusions were drawn with the use of comparisons between the Albanian Penal Code and the Criminal Codes of France, Germany, Italy and Kosovo. The selection of the first three codes is done not only by the weight and position they have in the continental system of criminal law, but also considering their longevity and durability in time. While the Kosovo Criminal Code is chosen because of its new age and the fact that it is framed based on the best European criminal codes.

\section{A Brief History of the Albanian Criminal Code and Innovations that have been Brought in Compared with the Penal Code of 1977}

2. Albania adopted its first Criminal Code in 1927, which entered into force on 1 January 1928. This Code continued in force, with some modifications and additions, up to the end of World War II. Following the liberation of the country, some transitory provisions of the law were adopted "On general criminal provisions" in December 1946, and the law "On the General Part of the Criminal Code" entered into force on 1 September 1948. Then, in 1952, the first complete Criminal Code of the communist regime was adopted, which continued in force until 1977, when the new communist Criminal Code was adopted. This Code continued to be in force (with some changes) even after the democratic changes of 1990. The new democratic Penal Code was approved by Law No. 7895, dated 27 January 1995, which entered into force on 1 June 1995. Although it brought in some changes in terms of dismantling the criminal law from its communist ideological basis (Muçi, 2012, p. 53), still in many of the General Part provisions that regulate the main components of the criminal law, it is substantially based on the communist Penal Code of 1977. This can also be ascertained if we look into the structure of the new Penal Code which resembles the Penal Code of 1977 (where although the number of articles in its General Part has increased slightly, it is still a long way from the number of articles in Western Europe Criminal Codes).

The new Criminal Code does not include many innovations in the General Part. It expressly brought in the principle of legality nullum crimen nullum poena sine lege, and provisions relating to relations with other countries (extradition) were added to and modified with criminal liability for offences committed abroad. In the new Criminal Code the age of criminal responsibility for committing contraventions went up to 16 years (from 14 years that was in the old Code, the same for crimes as for misdemeanours). The sentencing system also underwent some changes as the life imprisonment sentence was added, and fines for felonies, while two, more humane, sentences of "re-education through labour" and "social admonition" were removed. In addition, due to the devaluation of the Albanian currency Lek, the levels of fines for those convicted of crimes or misdemeanours was increased. However, the criminal responsibility provisions and specifically the forms of guilt, causality and circumstances of exception from criminal liability remained mainly unchanged.

The humanization and decriminalization of the new Penal Code presented a somewhat controversial situation compared with the previous Code (Elezi, Kaçupi, \& Haxhia, 1999, p. 14). Thus in the General Part some depenalizing and humane measures such as "Suspension of prison sentence", "Fragmentation of prison sentence", "Suspension of prison sentence and compulsory public service work", "Early release on parole", "Pardon", "Amnesty", "Prescription of prosecution" and "Prescription of the sentence's execution". On the other hand, this Code reflects a tendency toward stiffer sentences for some offences, including sentences of 25 years' imprisonment, life imprisonment and in certain cases even the death penalty (for 13 offences). In addition, a backward step in humanist terms of the new Penal Code was the abolition of the Article which did not consider as criminal offences those actions which had no social danger, although they formally may be regarded as a criminal offence by a specific provision of criminal law. 
The largest changes to the new Penal Code were in the Special Part. The Criminal Code of 1977 had only 200 articles in the Special Part (of which 39 were military offences and 161 were non-military offences), while the new Code originally had 262 offences in the Special Part (Elezi et al., 1999, p.13). The military offences are not included in the new Penal Code, but are separately incorporated into the Military Penal Code (Elezi, 2007, p. 11), which was approved by Law No. 8003, dated 28 September 1995. The increase in the number of offences is related to the economic changes from a centralized socialist economy to a free market, and with the opening of the country to developed Western societies, which has exposed Albanian society to new forms of criminality such as organized crime, economic crime, prostitution, narcotics trade etc.

On the other hand, in the new Penal Code some offences have been abolished which in the old Penal Code of 1977 were a function of the communist regime and had a conspicuous ideological content reflecting communist ideals. Such offences were "Diversion" (Article 52 of the Criminal Code of 1977), "Sabotaging the economy" (Article 53), "Agitation and propaganda against the state" (Article 55), "Activity against the revolutionary movement of the working class" (Article 60), "The exercise of prohibited trade" (Article 164), "Prohibited cohabitation" (Article 192), "Bigamy" (Article 193), "Avoidance of work (parasitism)" (Article 209) and "Gambling" (Article 236) etc.

Regarding the issue of sentencing severity specifically foreseen in the provisions of the Special Part of the (new) Penal Code it should be noted that they reflect an aggressive criminal policy. The enactment of life imprisonment sentences in 13 provisions of the Special Part indicates a hardening of the criminal sanctions for serious offences. In addition, if we make a comparison with similar provisions of the old Criminal Code of 1977 it can be seen that for some of them the sentences have been significantly aggravated. For example, Article 104 of the old Code provided a prison sentence of up to 3 years for the offence of "Fraud", while Article 143 of the new Code foresees a sentence of up to 5 years' imprisonment for this offence. Under Article 117 of the old Code "Escape of the convicted or detainees" there was a sentence of up to 3 years' imprisonment, while under Article 323 of the new Code it can be up to 5 years' imprisonment. Article 134 of the old Penal Code provided prison sentences of up to 10 years for "Production, keeping or selling of drugs", while Article 283 of the new Penal Code originally provided for a sentence of 5-15 years in prison for the same offence. Article 163 of the old Code had a sentence of up to 2 years in prison for "Selling contraband goods", while the new Code provides, in Article 178, for a sentence of 5 years' imprisonment. Article 197 of the old Code had a sentence of up to 2 years' imprisonment for "Falsification of documents", while the new Code, at Article 186, provides a sentence of up to 3 years' imprisonment. Article 224 of the old Code had a sentence of up to 2 years' imprisonment for "Production, holding or selling military weapons", while Article 278 originally provided for a sentence of 1-7 years in prison for weapons possession, and a sentence of 5-10 years in prison for their manufacture. Furthermore, for Articles 168, 169, 173, 174, 184, 201, 212 of the old Penal Code, more severe sentences are envisaged in the new Code. The difference between the harshness of the sentences in these provisions deepens if we consider that for the offences cited above, the old Criminal Code used to foresee a sentence of re-education through labour as an alternative sentence to imprisonment.

If a further comparison of the margins of the sentences between the old and the new Code is elaborated, it can be observed that in many of the other provisions such as Articles 97, 98, 106, 109, 110,121, 134, etc. (of the old Penal Code) lower minimum sentences at the bottom end of the range were foreseen (despite the fact that the maximum sentences may have been the same). For example, Article 109 of the old Penal Code envisaged a sentence of up to 10 years in prison for taking bribes (corruption) while Article 260 of the new Penal Code, for the same offence provides for a sentence of 3-10 years in prison. A difference in just one of the sentence margins (especially the minimum) directly affects the actual sentence levels that can be given by the courts to eventual perpetrators, as statistical data published by the Ministry of Justice shows that most of those convicted for less serious criminal offences are sentenced (by the courts) with sentences close to the minimum foreseen by the law.

From a comparative examination of these provisions it can be observed that it is only for offences of a political nature, which were against the communist dictatorial regime, that the old Code provided more severe punishments than the new code (offences mainly under the first, second and third headings of the Special Part of the Penal Code, that is, "Crimes against the state", "Crimes against the socialist property" and "Crimes against the socialist economic system", provided by Articles 47-82). For some of these offences in the old Criminal Code the prison sentences were 10-25 years, and in some cases the death penalty. Due to their ideological and political nature, most of the offences under these three headings are not included in the new Code and the rest have been redrafted (being incorporated into the offences against property, without distinguishing whether the property is public or private).

For the rest of the common offences such as intentional murder, murder in qualifying circumstances, murder committed in a state of profound psychiatric distress, serious intentional injury, theft, robbery, violation of road traffic rules, sexual relations with minors, sexual relations with violence, abuse of office, failure to report a crime, false denouncement, etc., both Codes provide the same or similar sentences. However, even for some offences in this 
category, characteristic of the 1977 Penal Code is the large tolerance between the minimum and maximum sentences foreseen by the provisions of the Special Part. Some of the offences against the person, even though providing a maximum sentence of 10 years in prison and in some cases even 15 years' imprisonment, start with a minimum of a month's imprisonment (which is the minimum imprisonment sentence according to Article 21 of the 1977 Penal Code).

Although Albania has been through one of the harshest communist dictatorships in Europe and the world, whose repression was implemented through the criminal law, a comparison of the sentence margins foreseen for many offences shows that in many cases the new Code of 1995 provides even more harsh sentences than the Code of 1977.

\section{Legal Changes in the New Penal Code After 1995}

\subsection{Overview of changes in the new Criminal Code}

The (new) Albanian Criminal Code must hold the world record for a law that has been changed the most within the shortest time. Since its entry into force in 1995 up to the present it has been changed by 15 laws (the latest being approved on 31 July 2014). The General Part of the Criminal Code initially had 72 articles, but these 15 changes brought in 10 new articles, and 27 existing articles were amended. The Special Part of the new Penal Code initially had 262 articles covering separate offences, but with these 15 laws amending the Criminal Code over the last 19 years, 300 articles of this Part have either been added or amended (i.e. more than the original number). As a result of the numerous changes to the provisions of the Special Part, it is hard to find any provisions that have remained intact since their approval, while there are some provisions that have been amended two or three times (for example Article 278 which has been amended six times).

Some of these changes (especially in the General Part) are justified by the need to ensure that the national legislation conforms to EU standards and the internal processes of socio-economic development that Albania has experienced in recent years (Muçi, 2012, p. 53). Nonetheless this does not fully justify such frequent amendments, because its integration processes and socio-economic development have not been so quick as to require almost yearly and complete changes in the Criminal Code. Under the continental law system other countries still have in force Codes that were approved before World War II, such as the Italian Penal Code of 1930, the Swiss Penal Code of 1937, and the German Criminal Code of 1871. For example, although the Italian Criminal Code was adopted at the time of the fascist regime, it has managed to withstand the major political, economic, social and constitutional changes that have occurred over the last 84 years in Italy (Fiandaca \& Musco, 2009, p. 48). All these Codes have seen amendments to the General Part and have also added or removed certain offences in the Special Part, but these interventions have been more rare and more mature.

Although it is considered that the new Albanian Penal Code is based on Western countries' Penal Codes such as those of France, Germany, Italy, and the Netherlands (Elezi, Kaçupi, \& Haxhia, 2006, p. 13; Mujaj, 2013, p. 33), we consider that it is closer to the Albanian Criminal Code of 1977 than these other Codes. If the provisions with ideological content were removed from the Penal Code of 1977, with the remaining articles regulating criminal responsibility, forms of guilt, sentences and imprisonment alternatives, this Code would be very similar to the new Penal Code. Furthermore, the paucity of articles provided at the time of approval of the new Penal Code both in the General and the Special Part does not support the argument that it was drafted based on the patterns of Western Criminal Codes. The Italian Criminal Code has 245 articles in the General Part and 521 articles in the Special Part (as well as other criminal offences provided outside of the Penal Code). The French Criminal Code has 195 articles in the General Part and 705 articles in the Special Part, while the German Penal Code has 137 articles in the General Part and 396 articles in the Special Part. Also the Kosovo Criminal Code has 120 articles in the General Part and 317 articles in the Special Part.

Although Shefqet Muçi makes a reasonable argument that the very fact of changing a large number of articles in the Criminal Code (37 articles in the General Part and 295 articles in the Special Part) is an indicator of large deficiencies since its approval (2012, p. 53), we do not agree about the way these changes were made and their frequency. The very frequent changes, such as those of 2003 (where within a year three laws were approved that changed certain articles of the Criminal Code) and those of 2004 and 2008 (in which, in both years, there were two laws approved that changed the Criminal Code) and the total of 15 amendments in 19 years is not fully explained by these arguments. These frequent interventions demonstrate the tendency of lawmakers (who are politicians) to present them before the public as a clear indication of their willingness to resolve the issue of criminality. Although the populist tendencies of politicians on criminal justice issues is a universal phenomenon (Bianchi, 1994, p. 334), it is the intensity and frequency of these interventions made in the new Albanian Penal Code which is unusual. 


\subsection{Changes to the Criminal Code regarding the adoption of new criminal offences}

Albanian legislation does not provide any express limitation on the Legislator regarding the criminalization of new behaviours. In the country's constitution and in the Penal Code there are no clauses outlining what conditions would determine whether certain conduct would be constituted by the Legislator as a criminal offence. This constitutional and political liberal spirit is also present in the domestic criminal literature. Following this liberal attitude of the Albanian legislation, some local authors of criminal law state that it is the Legislator who appraises (politically) if specific conduct will be considered a criminal offence or not (Elezi et al., 2006, p. 13), without setting any legal or even moral restrictions.

Although the constitutional system and the principles of the General Part of the Albanian Criminal Code do not impose explicit restrictions on the adoption of new criminal offences, from a logical viewpoint this does not legitimate the abuse of Parliament, with the power to approve frequent changes to the Criminal Code. These frequent changes, besides being able to substantially affect the quality of the Penal Code (by approving them hastily in order to meet the populist needs of a parliamentary majority), also violate the principle of legal certainty because they create confusion among citizens about the type of conduct that is considered criminal and about the type and level of criminal sanctions due. In the absence of stability and predictability in law, citizens have difficulty managing their affairs effectively (Eskridge \& Frickey, 1994). Although the principle ignorantia legis neminem excusat ${ }^{1}$ embodied in Article 4 of the Penal Code covers and reassures the state in terms of presumption of law knowledge of its citizens, it cannot avoid the obligation to make the law clear, predictable and sustainable. Furthermore, recently Andrew Ashworth (2011) put forward a strong critique of the doctrine that ignorance of the criminal law is no excuse, showing how preposterous the doctrine is and arguing that, even if it continues in a muted form, it should be accompanied by positive duties on the state to publicize its criminal laws.

Regarding the criminalization of conduct, many prestigious academics and scholars of criminal law insist on placing internal and external restrictions on the right of the state to adopt new criminal offences (Ashworth, 2006; Duff, Farmer, Marshall, \& Renzo, 2013; Husak 2008). According to Jonathan Herring (2012, p.17) the core principles that academics articulate, which the state should consider when adopting new criminal offences, are the principles of autonomy, damage and implementation in practice.

Some countries have established legal restrictions regarding the right of the state to adopt new criminal offences. The Criminal Code of Kosovo, which is one of the newest Criminal Codes in Europe and was adopted with the assistance of the best European and American experts (Salihu, 2012, p. 116) provides, in Article 1, that criminal offences and criminal sanctions can be brought in only for those actions that infringe and violate the freedoms, human rights and other rights and social values that are guaranteed and protected by the Constitution of the Republic of Kosovo and international law to the extent that it is not possible to protect these values without criminal sanctions.

The criminal law of a country is part of its legal system and, as such, it should be in accordance and harmony with it. The need for a rule of law and respecting it in practice comes from many branches of law such as civil law, labour law, family law, administrative law and criminal law. Citizens will become confused and law enforcement will fail if the norms of criminal law are not in harmony with civil or administrative law rules. If citizens are allowed to commit certain acts in civil or administrative law, it would seem illogical that such action could be forbidden by criminal law.

Between 1995 and 2014, in the Special Part of the Albanian Criminal Code, 120 new criminal offences were enacted and most of the existing ones were almost entirely changed, while only six existing articles were abrogated by the legislature (Articles 116, 227, 229, 239, 240 and 241) and an article by the Constitutional Court (Article 315). But with this extensive modification, no care was taken to ensure that the criminal law was in harmony with the legal system in general and with messages that government officials put out regarding state policy priorities in certain sectors. Two cases that demonstrate this contradiction in the Albanian legal system concern Articles 137/1 and 199/a of the Penal Code. The criminal cases to do with these two articles occupy a significant percentage of the total number of cases before Albanian courts.

Article 137/1 (added by Law No. 8733, dated 24 January 2001) criminally punishes the illegal reconnection of electricity by citizens. The quality of the electricity supply from the CEZ Company (recently changed to OSHEE) on the one hand and the payment of electricity bills by consumers on the other have been serious problems in Albania for 20 years (Ilahi, 2014). But besides the social aspect of the problem of non-payment of electricity bills (due to the poverty of part of the population) it has had large political implications as time after time the state itself has made amnesties for unpaid electricity bills (energjia.al, 2011). The culture of non-payment of electricity has been promoted repeatedly by successive governments on both sides of the political spectrum for electoral reasons, by tolerating abuses and neglect of

1 The Latin legal principle of "ignorance of the law does not excuse anyone", is a legal principle holding that a person who is unaware of a law may not escape liability for violating that law merely because he or she was unaware of its content. 
bill repayments to the supply company on the eve of electoral campaigns. Selective prosecution and punishment of some defaulting consumers in "law enforcement" campaigns and on the other hand tolerating the majority of abusing consumers, has not helped to address prevention of this offence.

The situation is the same with Article 199/a of the Penal Code which criminalizes illegal construction. This Article entered into force with the changes made to the Penal Code by Law No. 10023, dated 27 November 2008. Although it has been 5 years since this offence came into force, the number of illegal constructions has continued regardless, with high intensity, because despite criminalizing this conduct, the Legislator has so far approved three laws for the legalization of illegal constructions, namely Law No. 9482 (2006), No. 141/2013 and No. 50/2014. So, on the one hand the Legislator regards illegal construction as a criminal offence in the Penal Code, but, paradoxically, at the same time provides administrative laws for the legalization and legitimation of these illegal constructions.

The lack of deterrent effect of these two offences is directly related to the lack of cohesion and consistency of the whole judicial system with the restrictions that the criminal law provides.

\subsection{Changes to the Penal Code regarding the severity of criminal sanctions}

The issue of the severity of criminal sanctions in practical terms is a matter of greater concern than the issue of criminalization of behaviour, as the difference between a simple warning and a sentence of several years in prison is much greater than between declaring a defendant innocent and finding him guilty (when the court is giving a mild punishment such as an accessory punishment or a suspended sentence). As mentioned above, the numerous amendments to the Criminal Code, along with the enactment of new criminal offences and reformulation of existing ones, have affected most of the sanctions for these offences. Although we cannot cite here in detail all the changes made to criminal sanctions by the 15 amendment laws of the Penal Code, we will try to present their dominant tendency.

The first and most radical change to the system of criminal sanctions was made with Law No. 8175, dated 23 December 1996, which substantially raised the sentence limits (minimum and maximum) for many offences and imposed fixed sanctions for 45 offences (e.g. intentional murder was given 25 years' imprisonment, premeditated murder incurred life imprisonment or death, and exploitation of prostitution was raised to 15 years' imprisonment, etc.). The changes made by this law were abolished by Decision No. 13, dated 29 May 1997, of the Constitutional Court, on the grounds that they violated the principles of due legal process, right of defence and individualization of the sentence. Further, with Decision No. 65, dated 10 December 1999, the Constitutional Court declared the death penalty to be unconstitutional in peace time, which was included in the Criminal Code and the Military Penal Code.

Even though Law No. 8279, dated 15 January 1998, stiffened the sentences for three offences, with Law No. 8733, dated 24 January 2001, besides the enforcement of many new criminal offences, sentences for about 40 existing offences were additionally hardened. Also in the General Part of the Criminal Code the levels of fines for both felonies and criminal contraventions (misdemeanours) were increased. The same harsher trend is also observed with Laws such as No. 9086, dated 19 June 2003 (where the sentences for two offences were stiffened and in the General Part the possibility of simultaneously having imprisonment and a fine was brought in); Law No. 9188, dated 12 February 2004 (where harsher sentences for nine offences were brought in); Law No. 9275, dated 16 September 2004 (where the sentences for 12 offences were stiffened by adding fines alongside imprisonment); Law No. 9686, dated 26 February 2007 (hardening the sentences for 14 offences), and Law No. 9859, dated 21 January 2008 (making a harsher sentence for one offence).

With Law No. 10023, dated 27 November 2008, besides the enactment of many new criminal offences and harsher sentences for three existing offences, several articles were added to the General Part of the Penal Code, which expanded and clarified the application of alternative sentencing. These changes, along with the adoption of Law No. 10024, dated 27 November 2008, which created the Probation Service in Albania, paved the way for a wider application of alternative sentencing in practice (OSCE, 2010). There was a slight relaxing effect in criminal sanctions with Decision No. 47, dated 26 July 2012, of the Constitutional Court, which abolished the last paragraph of Article 29 of the Criminal Code as being incompatible with the Constitution (i.e. it abolished the possibility of the simultaneous assignment of a fine and imprisonment for the same offence), because, according to this court, ordering two principal sentences for Articles 190 and 191 of the Criminal Code at the same time would go against the grain with the principle of proportionality enshrined in Article 17 of the Constitution of the Republic. This Constitutional Court's decision brought an innovation into Albanian constitutional jurisprudence regarding the Legislator's right to determine the severity level of criminal sanctions and, together with Decision No. 19, dated 01 June 2011, paved the way for the possibility that in the future this court could assess the proportionality of sentences for certain criminal offences.

Despite this step towards softening and humanizing of the criminal law, with Law No. 23/2012 came harsher 
sentences for 20 offences, and Law No. 144/2013 brought stiffer sentences for 22 offences, while in the General Part the maximum prison sentence for crimes was raised from 25 to 35 years, and the most recent amendment, approved 31 July 2014 by Law 98/2014, brought in harsher sanctions for four offences.

From the above chronological presentation of amendments made to the Albanian Criminal Code it is noted that for the most part they have aggravated existing sanctions. To get a more specific idea about this phenomenon we can consider the evolution of sanctions for certain offences from 1995 until the present day. The offence of "Premeditated murder" (Article 78) in 1995 brought a sentence of 15-25 years in prison but it can now bring 20-35 years' imprisonment; the offence of "Possession of military weapons" in Article 278/2 of the Penal Code brought a sentence of a fine or imprisonment of up to 7 years, whereas currently if the weapon is held in a dwelling place, the sentence can be 5-8 years (Article 278/4), when held in a public place it is 7-15 years' imprisonment (Article 278/4) and if held in collaboration it may result in a sentence of 15-20 years' imprisonment (Article 278/5); the offence of "Illegal production and keeping of cold weapons" (Article 279) was punishable with a fine or imprisonment of up to 5 years, whereas actually keeping them in public places (Article 279/2) is punishable with 3-8 years' imprisonment.

The legislative tendency to address the solution to criminality issues only through intensification of punishments is wrong and should be stopped. The legislative initiatives for the addition of new offences and particularly stiffening the penalties for existing offences in the Criminal Code are presented by various governments as successful reforms and a clear expression of the will to fight crime (Parliament of Albania, 2013; Council of Ministers, 2014). But in reality, these initiatives have not only proved to be unsuccessful in reducing the crime rate, but in fact have rather have contributed to the overpopulation of Albanian prisons. From the Annual Statistics of the Ministry of Justice (2011) it is noted that the number of people found guilty and sentenced to imprisonment increased between 2004 and 2011. In 2011, 4909 people were sentenced with up to 5 years' imprisonment, of which only 1274, or 26 per cent, were suspended sentences. To solve the problem of prison overcrowding, in just 16 months the Albanian Parliament approved two amnesties, as a result of which many convicted people were released from prison (Law No. 107/2012 and Law No. 22/2014).

Turning once again to the modern Criminal Code of Kosovo (which in our opinion should be a model for the Albanian Penal Code), the second paragraph of Article 1 provides that "The criminal offences and the types of measures and the severity of the criminal sanctions for the perpetrators of criminal offences are based on the necessity of criminal justice enforcement and the proportionality of the level and nature of the danger for human rights and freedoms and social values". So we believe that too much punishment is wrong and, as with any other wrongdoing, it should be considered illegal and thus prohibited. Husak (2008, p. 13) states that "an adequate theory of criminalization could include a principle of proportionality, according to which the severity of the sentence should be a function of the seriousness of the crime". Punishment for doing wrong is justice, but excessive punishment is an injustice, especially when these laws restrict something that should not even be illegal.

\section{Concluding Remarks}

The new Penal Code of 1995, although having divested a lot of the ideological communist elements of the Penal Code of 1977, still has more similarities to the old Code than Western countries' Criminal Codes. Since the time of its adoption, the new Penal Code has suffered from many deficiencies in terms of defining and detailing the principles of the General Part, as well as in the definition of criminal offences in the Special Part. Since its approval, the Legislator has frequently intervened to amend the Criminal Code by adding principles and changing the institutes of the General Part, in an attempt to adapt it to contemporary democratic standards. Also to fill the multiple deficiencies and gaps, with the aim of responding to the concerns of society over the development of new forms of criminality, in the last 19 years the Legislator has enacted 120 new criminal offences. Similarly, it has become customary for legislative intervention in the Criminal Code to be continually stiffening the types and measures of sentences for many offences.

The frequent and unreasonable changes to the Albanian Criminal Code have a high element of populism and demagogy, since they are not based on scientific studies, or the practices of the Penal Codes of Western European countries. Aggravating the sentence measures and raising the minimum sentences for petty offences with low social danger, instead of bringing a measurable reduction of criminality, has led to an increase in the number of prisoners and subsequent prison overcrowding. The Legislator seems unable to look beyond amnesties, persistently relying on them as the only solution to prison overcrowding, despite their ineffectiveness in the long term.

As the Constitutional Court has stated, although the Legislator has a wide scope in setting the criminal offences and determining the type and severity of the sentences, this freedom should be limited by the principle of proportionality, which itself includes the reasonability and justifiability of a restrictive measure in relation to the needs that have driven it and the legitimate target aimed at. If criminal law continues to be considered as necessary to ensure peace and security 
even in modern democratic societies, this should not affect the need to be reasonable and more humane. In twenty-first century society the state should not be using criminal law "as a powerful weapon in fighting criminality", but rather as a "curative" democratic means for achieving peace and human prosperity.

\section{References}

Ashworth, A. (2006). Principles of criminal law. (6th edn.). Oxford University Press.

Ashworth, A. (2011). Ignorance of the criminal law, and duties to avoid it. The Modern Law Review, 74, 1-26.

Bianchi, H. (1994). Abolition: Assensus and sanctuary. A reader on punishment (pp. 333-351). New York: Oxford University Press.

Constitutional Court (1997). Decision No. 13, dated 29 May 1997, of the Constitutional Court.

Constitutional Court (1999). Decision No. 65, dated 10 December 1999, of the Constitutional Court.

Constitutional Court (2010). Decision No. 19, dated 1 June 2011, of the Constitutional Court.

Constitutional Court (2012). Decision No. 47, dated 26 July 2012, of the Constitutional Court.

Council of Ministers (2014). Report of Council of Ministers for the bill "On some additions and amendments to Law No. 7895, dated 27 January 1995, "Penal Code of Republic of Albania".

Dammer, R. H. \& Fairchild, S. J. (2006). Comparative Criminal Justice Systems. Canada: Stratford Publishing Services.

Duff, R.A., Farmer, L., Marshall, S.E., \& Renzo, M. (Eds.). (2013). The constitution of the criminal law. (1st edn.). Oxford, United Kingdom: Oxford University Press.

Elezi, l., Kaçupi, S., \& Haxhia, M. (1999). Penal Code Commentary, General Part. Tirana: Kumi Publications.

Elezi, I., Kaçupi, S., \& Haxhia, M. (2006). Penal Code Commentary, General Part. Tirana: Kumi Publications.

Elezi, I. (2007). Criminal law, Special Part. Tirana: Erik Editions.

energjia.al (2011). Enters into force the law for the remission of energy debts- benefiting categories. Retrieved October 31, 2001, from: http://energjia.al/2011/10/31/hyn-ne-fuqi-ligji-per-faljen-e-energjise-kategorite-qe-perfitojne/. Accessed on August 1, 2014.

Eskridge, W. N. Jr., \& Frickey, P. P. (Eds.). (1994). The Legal Process: Basic Problems in the Making and Application of Law by Henry Hart and Albert Sacks. Westbury, N.Y.: Foundation Press.

Fiandaca, G., \& Musco, E. (2009). Criminal law, General Part (6th edn.). Bologna: Zanelli editore s.p.a.

Herring, J. (2012). Criminal law (5th edn.). Oxford: Oxford University Press.

Husak, D. (2008). Overcriminalization: The limits of the criminal law. Oxford University Press.

Ilahi, N. (2014). Interview for Voice of America on July 10, 2014. Retrieved from: http://www.zeriamerikes.com/content/interviste-meshefin-e-fmn-per-shqiperine-nadeem-ilahi/1954780.html. Accessed on August 1, 2014.

Islami, H., Hoxha, A., \& Panda, I. (2003). Criminal Procedure Code Commentary. Tirana.

Kambovski, V. (2007). Criminal law, General Part (Albanian translation) (2nd edn.). Skopje.

Ministry of Justice (2012). Annual Statistics for 2011. Tirana.

Muçi, Sh. (2012). Criminal law, General Part (3rd edn.) Tirana: Guttenberg.

Mujaj, E. (2013). Changes in the Penal Code of the Republic of Albania concerning corruption. European Scientific Journal, 9(17).

Muncie, J. (2011). On globalisation and exceptionalism. In D. Nelken (Ed.), Comparative criminal justice and globalization (Advances in criminology), (pp.87-107) Farnham, England: Ashgate Publishing.

OSCE (2010). Handbook for application of imprisonment alternatives. Tirana: Pegi.

Parliament of Albania (2013). Record dated 03.04.2013 of the Legal Affairs Committee of the Parliament of Albania.

Salihu, I. (2012). Criminal law, General Part. (5th edn.). Pristina.

\section{Legislation}

Criminal Code of Albania (1927), approved by Decree No. 83-1, dated 28 May 1927.

Criminal Code of the People's Republic of Albania (1952), approved by Law No. 1470, dated 23 May 1952.

Criminal Code of the Socialist People's Republic of Albania (1977), approved by Law No. 5591, dated 15 June 1977.

Criminal Code of the Republic of Albania (1995), approved by Law No. 7895, dated 27 January 1995, updated in 2014.

Criminal Code of the Republic of Italy, updated in 2013.

Criminal Code of the Republic of Kosovo (2012), approved by Law No. 04/L-129, 20 April 2012, Pristina, Official gazette No. 19 / 13 JULY 2012.

Criminal Code of Germany in the version promulgated on 13 November 1998, Federal Law Gazette [Bundesgesetzblatt] I p. 3322, last amended by Article 3 of the Law of 2 October 2009, Federal Law Gazette I p. 3214.

Penal Code of France (2005) enacted on 22 July 1992 and entered into force on 1 March 1994, updated version of 2005.

Law "For granting amnesty" (2012), approved by Law No. 107/2012, came into force on 28 November 2012. Published in the official bulletin No. 148, dated 21 November 2012.

Law "For granting amnesty" (2014) approved by Law No. 22/2014, came into force on 10 April 2014. Published in the official bulletin No. 38, dated 26 March 2014.

Law No. 9482, dated 3 April 2006, on "Legalization, urbanization, and integration of illegal constructions".

Law No. 141/2013, dated 2 May 2013, for some changes and additions to Law No. 9482, dated 3 April 2006, on "Legalization, urbanization and integration of illegal constructions". 
Law No. 50/2014, dated 15 May 2014, for some changes and additions to Law No. 9482, dated 3 April 2006, on "Legalization, urbanization and integration of illegal constructions".

Law No. 8175, dated 23 December 1996, for some changes in Law No. 7895, dated 27 January 1995, "Criminal Code of the Republic of Albania".

Law No. 8204, dated 10 April 1997, for some changes in Law No. 7895, dated 27 January 1995, "Criminal Code of the Republic of Albania".

Law No. 8279, dated 15 January 1998, for some changes in Law No. 7895, dated 27 January 1995, "Criminal Code of the Republic of Albania".

Law No. 8733, dated 24 January 2001, for some changes in Law No. 7895, dated 27 January 1995, "Criminal Code of the Republic of Albania".

Law No. 9017, dated 6 March 2003, for some changes in Law No. 7895, dated 27 January 1995, "Criminal Code of the Republic of Albania".

Law No. 9030, dated 13 March 2003, for some changes in the law No. 7895, dated 27.1.1995 "Criminal Code of the Republic of Albania".

Law No. Nr.9086, dated 19 June 2003, for some changes in Law No. 7895, dated 27 January 1995, "Criminal Code of the Republic of Albania".

Law No. Nr.9188, dated 12 February 2004, for some changes in Law No. 7895, dated 27 January 1995, "Criminal Code of the Republic of Albania".

Law No. Nr.9275, dated 16 September 2004, for some changes in Law No. 7895, dated 27 January 1995, "Criminal Code of the Republic of Albania".

Law No. 9686, dated 26 February 2007, for some changes in Law No. 7895, dated 27 January 1995, "Criminal Code of the Republic of Albania".

Law No. 9859, dated 21 January 2008, for some changes in Law No. 7895, dated 27 January 1995, "Criminal Code of the Republic of Albania".

Law No. 10023, dated 27 November 2008, for some changes in Law No. 7895, dated 27 January 1995, "Criminal Code of the Republic of Albania".

Law No. 23/2012, dated 1 March 2012, for some changes in Law No. 7895, dated 27 January 1995, "Criminal Code of the Republic of Albania".

Law No. 144/2013, dated 2 May 2013, for some changes in Law No. 7895, dated 27 January 1995, "Criminal Code of the Republic of Albania".

Law No. 98/2014, dated 31 July 2014, for some changes in Law No. 7895, dated 27 January 1995, "Criminal Code of the Republic of Albania". 